\title{
STRATEGI PROGRAM KESEHATAN PUSKESMAS DI SEKOLAH DASAR
}

\author{
Treesia Sujana $^{1}$, Angkit Kinasih ${ }^{2}$, Makmur $^{1}$ \\ ${ }^{1}$ Program Studi S1 Keperawatan Fakultas Kedokteran dan Ilmu Kesehatan, \\ Universitas Kristen Satya Wacana \\ ${ }^{2}$ Program Studi S1 Pendidikan Jasmani Kesehatan dan Rekreasi Fakultas Kedokteran dan Ilmu Kesehatan, \\ Universitas Kristen Satya Wacana \\ Email: treesia.sujana@staff.uksw.edu
}

\begin{abstract}
ABSTRAK
Latar Belakang: Usia anak merupakan usia yang rentan terhadap penyakit, kegiatan pelayanan kesehatan gigi dan mulut adalah Upaya Kesehatan Gigi Sekolah (UKGS) yang merupakan upaya promotif dan preventif kesehatan gigi khususnya untuk anak Sekolah Dasar. Puskesmas memiliki program Promosi Kesehatan di Sekolah Dasar, dimana keberhasilan program ini terutama tergantung pada kemitraan antara instansi terkait, terutama Puskesmas dan Sekolah Dasar.Tujuan: mendeskripsikan usaha kegiatan promosi kesehatan Puskesmas Getasan di Sekolah Dasar. Metode Penelitian: Penelitian ini merupakan penelitian kualitatif dengan pendekatan deskriptif. Data dikumpulkan dengan wawancara mendalam (in-depth interview) menggunakan pedoman wawancara. Penelitian ini dilakukan di daerah Puskesmas Getasan Kabupaten Semarang Kota Salatiga Provinsi Jawa Tengah pada bulan Januari sampai bulan Maret tahun 2017. Partisipan dalam penelitian ini berjumlah 5 orang yang didapat dengan menggunakan tehnik purposive sampling. Penelitian ini menggunakan analisa data Miles dan Humberman. Hasil Penelitian: Dalam penelitian ini ditemukan bahwa strategi pendidikan kesehatan yang dilakukan terhadap anak usia sekolah dengan cara mempraktekkan langsung di lapangan yang berkaitan dengan materi pendidikan yang akan diberikan terhadap anak usia sekolah. Kesimpulan: Hasil dari penelitian ini bahwa usaha kegiatan promosi kesehatan Puskesmas di Sekolah Dasar sudah cukup baik dan sesuai dengan harapan tenaga kesehatan yang memberikan promosi kesehatan di Sekolah Dasar dengan fasilitas yang cukup dan dukungan antara orang tua dan petugas kesehatan sehingga kegiatan tersebut berjalan dengan baik dan berdampak positif bagi peningkatan kesehatan anak diusia Sekolah Dasar.
\end{abstract}

Kata kunci; Puskesmas, promosi kesehatan, pelajar sekolah dasar

\section{Abstrac}

Background: Children's age is vulnerable age toward diseases. That is why Health efforts school teeth (UKGS) try to promote and prevent sickness toward the dental health and oral health for the elementary school students. Puskesmas has the health promotion program in the elementary school, where the success of this program is depend on the partnership between the stakeholders. Puskesmas and the elementary school is the prior subject. Research purposes: Theis research goal on this study is to describe the Puskesmas Getasan's promotion efforts, in the elementary school. Method: This stdy used a qualitative method with a descriptive approach. The data had beens collected by an indepth interview method and with the using of interview guidelines. This study had been done in the Puskesmas Getasan, Semarang district, Salatiga city, Middle Java on January until March 2017. The participants of this research are five peoples, which were gathered through purposive sampling method. This research also used Miles and Humberman data analysis. Result: In this research found that strategy education health was done with school age children by means of practice in the field pertaining to matter educations to be provided to school age children.Conclusion: The result of this research showed that huge efforts has been done in order to give health promotions in elementary school and suitable with the goal which been made by the health staff, which are to give health promotions with decent facilities and with full support of parents and health workers. Thus, with all the support and facilities, all the efforts brought positive impact toward the elementary student health status.

Key words: Puskesmas, health promotion, student elementary school 